until a new way of allocating the leases has been worked out.

However, FCC did not rule out the auction idea completely, and has invited the company to make alternative proposals for selecting bidders that would not contravene federal regulations. One is that sealed bids should be invited, and leases awarded to the seven highest bidders at the price offered by the lowest of the seven.

The dispute between RCA and FCC over how to allocate the leases reflects a gradual shift in attitudes towards the regulation of access to telecommunications satellites. In the early 1970s, when the satellites were first coming into service, the federal government introduced strict regulations to prevent manipulation of the market.

In practice, this goal has been achieved through classifying companies such as RCA which launch the satellites as "common carriers" which are required to offer leases on their transponders on a firstcome, first-served basis at prices that are strictly regulated by FCC. The procedure has been effective in protecting smaller users from being squeezed out of the satellite communications market; it has also made it difficult for companies to stockpile transponders, even if they have no immediate need for them, in order to exclude their competitors.

Recently, however, concern has been growing about speculators who have bought leases at the regulated prices and resold them at a considerable profit. In addition, the growth of available space on satellites has lead the industry to argue that tight federal regulation is no longer needed. The cause of deregulation of the telecommunications satellite industry has also been embraced by the members of FCC, which in a 7-0 vote last week agreed to publish for public comment new rules which would allow companies operating satellites to negotiate sales directly with private customers.

Satcom IIIR, launched successfully from Kennedy Space Center in November, contains 24 transponders, eight of which were reserved for those who had bought space on the ill-fated Satcom III which failed to go into orbit after its launch in December 1979.

Both Satcom IIIR and Satcom IV are dedicated to use by cable television companies. The satellites are intended to transmit programmes to local television operators, which would then distribute them to individual homes. Since an antenna can only pick up signals from a single satellite at any one time, the companies have been keen to band together rather than lease space on other commercial satellites, such as Westar 1 and Comstar D2.

Among the companies which will have to renegotiate the transponder leases with RCA is RCTV, a joint venture of RCA and the Rockefeller Center Inc., which has announced ambitious plans to distribute

\section{Cashing in now}

British Telecom, exercising its right under last year's Telecommunications Act to form partnerships with commercial enterprises, has launched a company to exploit spin-off from research at its laboratories at Martlesham Heath, Suffolk.

The plan is to set up small venture companies to exploit ideas, although patents may be available under licence to existing manufacturers. The new company, Martlesham Enterprises, has been set up with $£ 250,000$ of issued ordinary share capital, the shareholders being British Telecom (30 per cent), Electra Investment Trust (25 per cent), Lazard Brothers (20 per cent), Raeburn Investment Trust (managed by Lazards) (20 per cent) and Thompson Clive and Partners (5 per cent).

Research at the Martlesham Heath laboratories covers optical fibres, semiconductors, video-phones, slow-scan TV, speech synthesis and public viewdata systems. Martlesham Enterprises has already identified five ideas which could form the basis for new manufacturing companies, but so far only one of them, a new materials process for semiconductors, has been developed to any significant extent.

Martlesham Enterprises plans to hold a financial interest in new operating companies, giving its shareholders first option to put up new capital. Attractive terms are to be offered to inventors who leave the laboratories to help set up new companies. Interest on profits will, as normal, return to the shareholders. It is hoped that the operating companies will grow to the point where they can be launched publicly, when Martlesham Enterprises will decide whether to retain a financial interest or dispose of them.

Judy Redfearn

entertainment programmes through cable television. The company has already agreed to buy the first rights of British Broadcasting Corporation programmes for transmission in the United States.

Meanwhile, in a separate move illustrating the social and political possibilities being opened up by satellite telecommunications technology, four labour unions have joined with the American Federation of Labor/Council of Industrial Organizations to arrange for the broadcast over public television of two films on safety and health whose distribution had been suspended by the Department of Labor's Occupational Safety and Health Administration. The unions have made use of a 1978 amendment to the 1934 Communications Act which allows groups outside public broadcasting to rent time on one of the four transponders which the Public Broadcasting Station (PBS) leases on the satellite.

\section{Technical change in France}

\section{Central theme}

The French government is to set up a centre for social and systems research on science and technology, inspired to some extent by the Brookings Institution of Washington and, in Britain, the Technical Change Centre in London and the Science Policy Research Unit (SPRU) in Sussex. But in the Paris institution there will be a difference: it will be strictly linked to, and under the direction of, the Ministry for Research and Technology, and will thus lack the political independence of its models.

The Center for Advanced Technological Systems Study (CATSS), to use its Americanized name, (CESTA, Centre d'études des systèmes et des technologies avancées, in French) should be in full swing by 1984 with a budget of around 40 million francs and a staff of 40 "scientists and engineers".

The creation of CATSS is the immediate result of a report to Prime Minister Pierre Mauroy by Dr Joël de Rosnay, director for research applications at the Institut Pasteur (where Francois Gros, science adviser to the Prime Minister, was until recently director). De Rosnay recommended that a centre like CATSS be established "to study the industrial, social and cultural change induced by advanced technological systems (such as microelectronics, biotechnology, robotics and solar energy)',

The questions are political and involved, the report notes, and it claims that in France "there are traditional difficulties" in thinking in terms of complex systems and networks. CATSS must overcome these difficulties.

As a government agency in a government devoted to industrial development through technology, CATSS may find its emphasis lying more frequently on innovation strategy in key industries than on social impact perse. The emphasis of the report is on missed, or botched, industrial opportunities: Concorde, an "indisputable technical success" marred by a failure to anticipate economics, competition and environmental impact; microelectronics, insufficient in France because opportunities to develop liquid crystals and integrated cricuits were not taken up; and biotechnology, limited by the lack of researchers and engineers trained in the life sciences.

Despite its government links, the centre will be open to scientists, industrialists, union leaders, parliamentarians and local politicians. It will also collaborate with outside institutions (including, perhaps, Brookings, SPRU and the Technical Change Centre).

CATSS will have a strong training function as well as undertaking research, experimenting with new educational technology and communications systems, 
and helping to "diffuse" new technology. Thus the concept appears to be of an intellectually and politically sophisticated institution to assist the country's technological development: one which will be able to help industry to make its forecasts and plans, but will, at the same time, take into account likely social impacts and obstacles. CATSS's first programmes begin next month - training programmes in biotechnology and microelectronics. A director for the centre is expected to be appointed before the summer.

Robert Walgate

\section{Fluoridation in Scotland}

\section{Days in court}

A legal trial that will decide whether Strathclyde Regional Council becomes the first Scottish water authority to add fluoride to its water supply has now passed its 130 th day, making the record books as the longest ever court case to be heard in Scotland. The Edinburgh Court of Session, Scotland's High Court, has become a battleground for fluoridation and anti-fluoridation interests.

The case, McColl v. Strathclyde Regional Council, opened on 23 September 1980 , and was originally expected to last twelve weeks. The eventual cost is estimated at $£ 1$ million, which would make it the most expensive civil case in Scottish legal history. The costs of Strathclyde Regional Council will be met by its four area health boards. The expense of an expert witness can be as much as $£ 450$ a day and many have come from as far away as the United States and Australia. If the case lasts for 150 days, as it may well do, lawyers' costs alone could exceed $£ 60,000$.

The issue at stake is twofold - the legal right of the council to add a trace of fluoride to the water supply and the medical effects of fluoride. In 1977, the council voted by a majority of 43 to 42 to build a $£ 2$ million plant to introduce fluoride into the water supply. Mrs Catherine McColl is contesting the decision, claiming the right of herself and her grandchildren to drink unfluoridated water on the grounds that fluoride is not only useless but can cause cancer and other diseases. The hearing is before Lord Jauncey.

The evidence has been intricate and technical. Mrs McColl appeared in the box only on the first day. The medical issues have focused on the contention that fluoride can cause cancer. Sir Richard Doll for example, has so far given evidence for two weeks. It is expected that Lord Jauncey will take months to reach a judgement.

Evidence against fluoridation has been given by Dr John Yiamouyiannis, formerly of the National Health Federation organization and a member of the US National Health Action Committee, and Dr Dean Burk, a retired National Cancer Institute laboratory scientist. In some ways the
Scottish trial is a re-run of the hearing in West View, Pennsylvania in November 1978, when Drs Yiamouyiannis and Burk also argued that there is a link between fluoride and increased cancer mortality rate. Dr Burk has separately told the US House of Representatives that fluoridation is "socially imposed murder".

In Pennsylvania, Judge Flaherty, then a lower court judge, issued an injunction ordering West View Water Authority to cease water fluoridation. His decision, however, was appealed against on grounds of jurisdiction. In January 1979, after a review of the evidence by the Department of Environmental Resources, the water authority was ordered to continue to fluoridate. The Minnesota Governor's Commission, appointed in 1978 to study the health effects of water fluoridation, examined the same body of evidence as Judge Flaherty and concluded that "an association between fluoridation and cancer has not yet been shown".

Fluoride has been added to water supplies in Britain since 1957, and 10 per cent of the population drinks artificially fluoridated water (in the United States 44 per cent of the population drinks treated water). The 1972 Water Act enjoins the water authorities to provide "wholesome water', but although 87 out of 90 area health authorities are in favour of fluoridation, in the past 7 years few schemes have been implemented. The water authorities seem reluctant to proceed in the absence of parliamentary legislation.

The decision in Scotland could thus be influential, particularly as a similar case is being prepared in Calderdale, Yorkshire. If Lord Jauncey decides in favour of Strathclyde, the issue of further legal aid for an appeal will arise. If the case goes to the House of Lords, it may take several years for a final decision. And neither side may be able to claim a victory - if, for example, the judgement is that fluoride is beneficial to dental health but that water authorities do not have full jurisdiction to determine what goes into the water supply.

In Strathclyde, the irony is that local elections early this year could render any judgement nugatory: a new council could vote to reverse the fluoridation policy.

Jane Wynn

\section{Rubik's cube \\ Puzzles galore}

A decision is expected this week from the British high court hearing of a copyright and passing-off suit brought by the Politehnika Industrial Corporation of Budapest, manufacturers of the original Rubik's cube, against Dallas Print Transfers of London, importers of an alleged copy known as the "Wonderful Puzzler", produced in Taiwan.

The case, initiated by an injunction from Politehnika last March, has turned on two main issues. As far as copyright is con- cerned, the emphasis has been on the internal structure of the cube, involving comparison of production blueprints, while the passing-off charge is based on claims that the puzzler has on occasion been marketed as the Rubik cube.

The dual nature of the case corresponds appropriately to Dr Erno Rubik's own dual interest in the cube - structure and concept. A lecturer in architecture at the Budapest Academy of Applied Arts, he was, he says, originally interested primarily

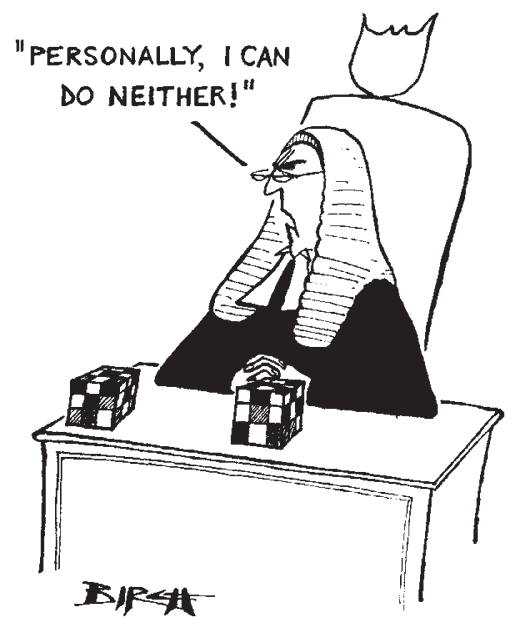

in the internal mechanism of the cube which allows each face, consisting of a $3 \times$ 3 array of cubelets, freely to rotate either clockwise or anticlockwise. Only later did he decide to communicate his pleasure in the new device to others by offering it for commercial construction.

Rubik says that other international contributions to the booming market in logic toys - pyramids, spheres and the like embody essentially the same principle as the cube, since the various sections are displaced without changing the over-all shape of the assemblage. The one major exception, known as the "tower", which exists in two contending Hungarian versions, is, in his opinion, simply the old " 15 puzzle" invented in the 1880 s, rolled up into cylindrical form, since it incorporates a vacant parking spot into which an element can be moved during the transfer process.

The popularity of the cube, which Rubik himself cannot adequately explain, has made him reputedly the seventh richest man in Hungary and won for him a "Gold Medal of Labour" for his services to Hungarian industry, and has had a number of unexpected spin-offs. The possible and impossible configurations of the cube, Rubik said last December, were attracting attention from physicists as a means of modelling the properties of quarks.

In Hungary, the unprecedented boom in the toy industry generated by the cube has highlighted a number of defects in the New Economic Mechanism, and seems to have been in part responsible for the recent relaxation of the rules governing small enterprises. 